\title{
THE COPPER AND NON-HEMOGLOBINOUS IRON CONTENTS OF THE BLOOD SERUM IN DISEASE ${ }^{1}$
}

\author{
By ARTHUR LOCKE, E. R. MAIN, AND D. O. ROSBASH
}

(From the Henry Baird Favill Laboratory of St. Luke's Hospital and the Department of Chemistry of the University of Chicago, Chicago)

(Received for publication January 18, 1932)

This is a report of an investigation into the extent to which the copper and non-hemoglobinous iron levels of the blood serum are shifted in disease, and the extent to which the shifted levels may reflect underlying disturbances of tissue respiration and metabolism.

The levels of copper and non-hemoglobinous iron in the blood serums of fasting individuals are determined by balances between the rates at which the metals are drawn or excreted from the cells and the rates at which they are excreted from the body. In the absence of changes in the rates at which the metals are excreted from the body, increased levels in the serum signify decreased levels within the cells, and vice versa.

Increases in the copper content of normally respiring cells would appear to be accompanied by a reduction in the intensity of their metabolism. The respiration of the unripe Arbacia egg decreases progressively as the content of copper increases. Following fertilization, the copper content becomes reduced, as the result of the excretion of a "copperavid" substance into the supporting medium, and the rate of respiration rises (1). Additions of copper to cultures of baker's yeast are followed by proportionate decreases in the rates of respiration and glucolysis (2). Concentrations of copper equivalent to those present in human serums are not only partially inhibitory to respiration and glucolysis but also to proteolysis (3) (4) and lipolysis (5) (6) as encountered in the cells which make up mammalian tissue.

Increases in the iron content of living cells would appear to be followed by an augmentation of metabolism. Additions of iron to cultures of the anaerobic $\mathrm{Cl}$. sporogenes are followed by increases in metabolism of such intensity as to lead to the disintegration of the organisms (7). Comparable additions to cultures of baker's yeast are without effect (2). Aerobic cells appear to have a mechanism for holding the iron level within a tolerable range, presumably through the removal by oxidation and excretion of all but a minimal fraction of the catalytic iron intake. Impairment of this mechanism through a restriction of the oxygen intake may, in healthy 1931.

${ }^{1}$ Presented before the Central Society for Clinical Research, November 20, 
animals, be followed by a temporary stimulation of metabolism, reflected in an increased rate of production of red blood corpuscles and an augmentation of functional activity in general (8). In tumor cells, where the oxidation mechanisms may be defective (9), ferrous iron may tend to accumulate to a level sufficiently high to initiate the increased rate of growth, death, and autolysis which is associated with the development of tumor tissue.

The first determinations of the copper and non-hemoglobinous iron contents of human serum were published by Warburg and Krebs in 1927 (10). The analyses were made by a catalytic method, developed by Warburg (11), which appears to give accurate values in the hands of persons trained in its use. The series was extended to a total of eightynine serums by Krebs in 1928 (12), the added analyses being restricted to determinations of copper content. The serums of ten normal individuals were examined. Separation of the figures reported into values characterizing men and values characterizing women indicates an average copper level for the former of 0.82 microgram and for the latter of 0.98 microgram per cc. The average copper level for twelve persons with pulmonary tuberculosis was $\mathbf{1 . 5 5}$ microgram per cc., for thirteen women in the final months of pregnancy, 2.07. Analyses of the serum in other conditions also were reported, the values being, on the whole, comparable to those reported herewith.

Analyses of whole blood for copper have been made by Schindel (13), using the Schönheimer-Oshima modification (14) of the Spacu-Biazzo method (15), a method which is not practicable for general use because of the large amount of sample required. The values appear to be high. They corroborate the distribution of copper between the maternal and fetal blood reported by ourselves, and the distribution of copper between the plasma and corpuscles reported by Flinn and Inouye (16). Additional analyses of human blood for copper have been reported by Schönheimer and Oshima (14), Kleinmann and Klinke (17), Herkel (18), and Grendel (19).

Analyses of the bloods of other species are reported by $\mathrm{McHargue}$ (20), the pioneer in the field, and by Warburg and Krebs (10), Abderhalden and Möller (21), and Grendel (19). The values for the copper content of horse serum reported by Elvehjem, Steenbock and Hart (22) are out of line with the results obtained by ourselves and others. Their method of ashing is possibly not adapted to serum because of the risk of volatilizing copper chloride.

The values reported by Warburg and Krebs for the non-hemoglobinous iron contents of human serums would, perhaps, have been in closer agreement with those reported herewith had more determinations been made. The values reported by Riecker (23) (24), using a method similar to our own, are, singularly enough, approximately ten times too high. 
The rise of the iron level in untreated pernicious anemia and its correction following liver therapy, as observed by Riecker, are confirmed in this report, as are his observations of a lowered iron level in anemia secondary to hemorrhage. The latter observation has been reported also by Fontès and Thivolle (25).

Values for the iron content of the serums of species other than man have been reported by Barkan (26), Starkenstein and Weden (27), Warburg and Krebs (10), Henriques and Roche (28), Abderhalden and Möller (21), and Fontès and Thivolle (25).

\section{METHODS}

The following procedures permit the determination of the copper and nonhemoglobinous iron contents of ten cc. of fresh blood serum with an accuracy of \pm ten per cent and with the time, apparatus, and technic at the disposal of the ordinary clinical laboratory.

Ten cc. of the serum to be examined are measured into a carefully cleansed, well seasoned $50 \mathrm{cc}$. centrifuge tube. An equal volume of a 20 per cent solution of redistilled trichloracetic acid is added and the well suspended mixture permitted to stand for 2 hours, with occasional resuspension, before centrifugation for 30 minutes at a speed of 1500 rotations per minute. Two portions, 4 cc. and $3 \mathrm{cc}$., of the clear supernatant liquid are transferred to $125 \mathrm{cc}$. glassstoppered Erlenmeyer flasks for copper analysis. Two further portions of $3 \mathrm{cc}$. and $2 \mathrm{cc}$. are transferred to similar flasks for iron analysis. Equivalent volumes of 10 per cent trichloracetic acid are taken for use as blanks.

Copper analysis. Each aliquot is diluted with glass-distilled water, together with the blank and, occasionally, a reference control, to a volume of $9 \mathrm{cc}$. One drop of 1 per cent phenolphthalein is added, followed by a sufficient volume of a saturated solution of metal-free sodium hydroxide to produce a stable red color. The color is discharged by the addition of an excess of 3 drops of glacial acetic acid. Approximately $0.2 \mathrm{cc}$. of pyridine ${ }^{2}$ are added and $1 \mathrm{cc}$. of a 1 per cent solution of Eastman's sodium diethyl dithio carbamate which is free of sediment. ${ }^{3}$ The mixtures are permitted to stand for 1 hour, when exactly 2 cc. quantities of amyl alcohol are added. After vigorous shaking, and standing for the 2 to 3 minutes required for the separation of the water and alcohol layers, the latter are transferred to small test tubes with Pasteur pipettes equipped with small rubber suction bulbs. In the unusual event that the iron content of the sample is greatly in excess of the copper content, the alcohol extracts may have a transient brown-black tinge which must be allowed to fade before making the colorimetric comparison with the standards. The extracts are ordinarily a stable, clear yellow in color. The color of the standards is developed at the same time and in the same way as that of the unknown supernatant. It is convenient to use standards containing 1.5 to 2.0 micrograms of copper per $2 \mathrm{cc}$. of alcohol extract, and to prepare them from a solution of copper sulphate in $0.01 \mathrm{~N}$ sulphuric acid which contains 5 micrograms of copper per cc.

2 The pyridine does not enter into the composition of the color complex.

3 The use of this reagent for the detection and estimation of copper was first recommended by Callan and Henderson (29). The procedure for iron analysis is adapted from a method proposed by R. P. Kennedy (30). 
Iron analysis. No water is added. The stoppers of the flasks are removed, 1 cc. of redistilled sulphuric acid and 3 drops of perhydrol are added, and the mixtures kept on an asbestos-covered hot plate, at a temperature sufficient to maintain $50 \mathrm{cc}$. of water in a similar container at a temperature of 75 to $85^{\circ} \mathrm{C}$., until incipient charring is manifested by a distinct yellow or brown coloration in the digest. A sufficient volume of a $0.05 \mathrm{~N}$ solution of iron-free potassium permanganate is added to the partly cooled digests to accomplish their decolorization. Not more than 2 to 3 drops should be required. Approximately $15 \mathrm{cc}$. of glass-distilled water are added and the heating resumed for 30 minutes. The contents of the flasks are cooled, the stoppers replaced, and 2 more drops of permanganate solution added. Exactly $2 \mathrm{cc}$. of amyl alcohol are added while the permanganate color still persists and are followed at once by the addition of $10 \mathrm{cc}$. of a 20 per cent solution of iron-free potassium thiocyanate. After thorough shaking, the flasks are allowed to stand for 2 to 3 minutes. The alcohol layers are removed, and the colors compared with those of standards, as described in the section on copper analysis. The colors of the standards should be closely equivalent to those of the unknowns with which they are to be compared and readings should be made rapidly before appreciable fading can occur. It is convenient to have ready a series of standards containing $0.5,1.5$, and 2.5 micrograms of iron per $2 \mathrm{cc}$. of alcohol extract, and to prepare them from a solution of ferrous ammonium sulphate in $0.01 \mathrm{~N}$ sulphuric acid which contains 5 micrograms of iron per cc. The iron standards contain $1 \mathrm{cc}$. of sulphuric acid in the $15 \mathrm{cc}$. of their total volume but are not heated and contain no perhydrol or trichloracetic acid.

The colorimetric comparisons may be made, with accuracy, in inexpensive 6 to $8 \times 75 \mathrm{~mm}$. tubes with optically flat bottoms. The tubes are covered with black paper and the contents compared by looking through at a white porcelain surface, well illuminated by reflected sunlight. The lengths of the liquid columns are varied with the aid of the Pasteur pipettes used for the isolation of the alcohol extracts and the readings made by application of a small straight-edge ruler.

The copper and iron blanks should not exceed 0.4 microgram in total amount and must be determined with the same care as the metal contents of the samples themselves.

The amounts of copper and non-hemoglobinous iron in $1 \mathrm{cc}$. of serum are, within the limits of error inherent in the method, twice those present in the trichloracetic acid extract used for analysis.

Copper, in amounts appreciably in excess of those encountered in human serum, tends to interfere with the redness of the color normally produced by ferric ion with thiocyanate. Iron does not seriously interfere with the determination of copper, by the procedure described, even when present in amounts considerably in excess of those found in human serum. The presence of a trace of hemoglobin in the serum does not affect the recovery of either copper or iron.

\section{Normals}

Table 1 presents the distribution of copper and non-hemoglobinous iron in the blood serums of a group of hospital employees, apparently well and actively engaged in work. The blood was obtained in carefully cleansed and dried containers before breakfast and kept in the refrigerator for three to six hours before separation of the serum by centrifugation. The analyses were carried out as has been described. 
TABLE 1

The copper and non-hemoglobinous iron contents of the blood serums of a group of twentyeight "normal" adults

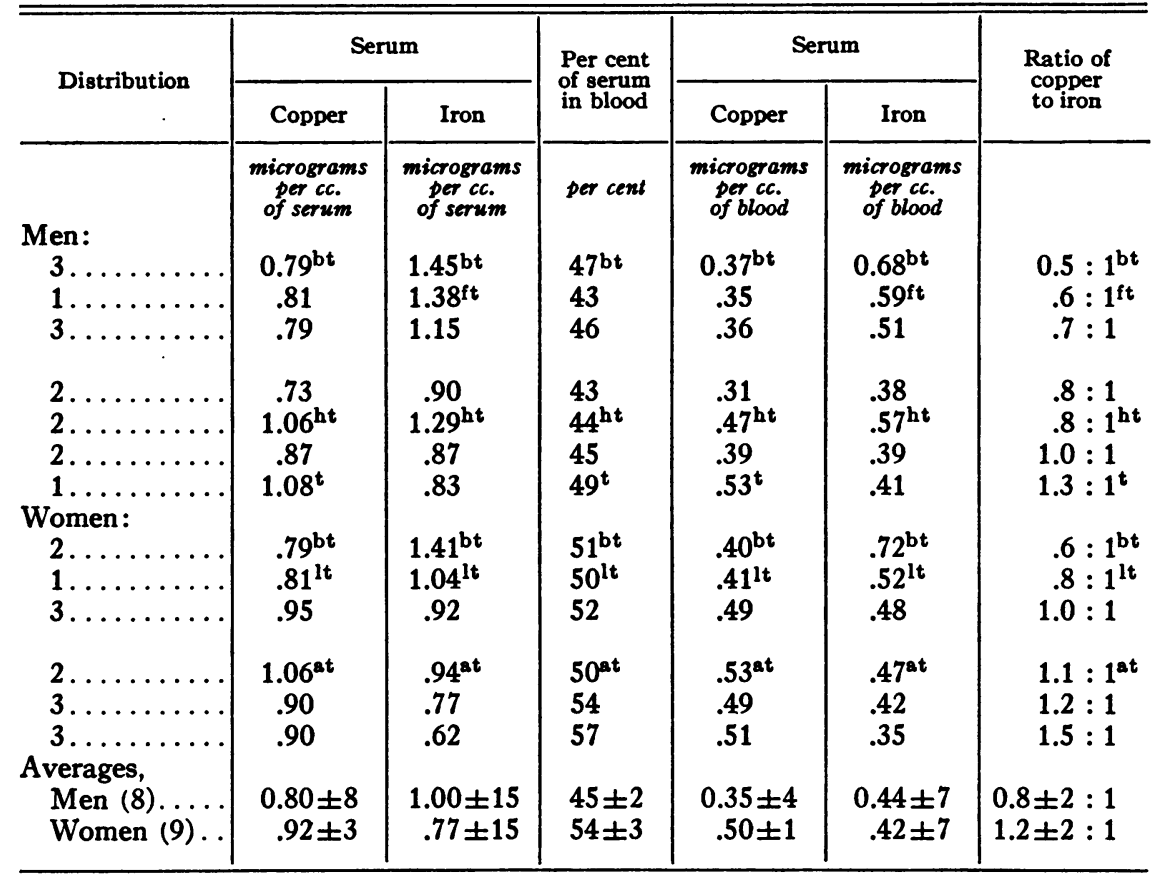

a: age more than 50 yrs., b: bilirubinemia, $f$ : fasting interval more than 12 hours, h: later found to have a high basal metabolic rate, 1 : later found to have a low basal metabolic rate, $t$ : not considered in the averages.

The presence of bilirubin was apparent in several of the serums examined, through the bluish green color of the products of oxidation carried into the trichloracetic acid precipitates during the preparation of the samples for analysis. These serums appeared to contain more iron than serums giving a colorless precipitate with trichloracetic acid. They were not considered in the computation of the averages.

Others of the group could not be considered in the averages for the reasons indicated in the footnotes appended to Table 1.

The majority of the men had lower, and more variable, copper levels, and higher iron levels than were found in the majority of the women. The women's blood contained more serum than the men's blood. The differences in the copper levels of the two sexes became accentuated, and the differences in the iron levels minimized, when this factor was taken into account. The copper : iron ratio characteristic of the majority of the women was approximately 50 per cent higher than that characteristic of the majority of the men. 
The women's serums were selected and examined with the possibility of the existence of a cyclic variation of the copper and iron levels in mind. None was observed.

\section{Conditions in which the iron content of the serum is increased}

The non-hemoglobinous iron content of the blood serum was uniformly above the normal, twelve-hour fasting level in only two of the abnormal conditions which came to our attention, namely, untreated pernicious anemia and icterus.

Extension of the fasting interval from twelve to twenty-four hours is attended, in normal persons, by a twenty to fifty per cent increase in the iron level, a five to ten per cent increase in the copper level, and an indeterminate increase in the bilirubin level.

The high iron levels observed in untreated pernicious anemia compare

TABLE 2

The effect of extension of the fasting interval on the copper and non-hemoglobinous iron contents of the serum. The effects of pernicious anemia and icterus

\begin{tabular}{|c|c|c|c|c|}
\hline \multirow{2}{*}{ Subjects } & \multicolumn{2}{|c|}{ Serum } & \multirow{2}{*}{$\begin{array}{l}\text { Ratio of } \\
\text { copper } \\
\text { to iron }\end{array}$} & \multirow{2}{*}{$\begin{array}{l}\text { Bilirubin } \\
\text { content }\end{array}$} \\
\hline & Copper & Iron & & \\
\hline & $\begin{array}{l}\text { micrograms } \\
\text { per cc. }\end{array}$ & $\begin{array}{l}\text { micrograms } \\
\text { per cc. }\end{array}$ & & \\
\hline \multicolumn{5}{|l|}{ Normal persons, ${ }^{*}$} \\
\hline After fasting for 12 hours. & 0.77 & 0.75 & $1.0: 1$ & - \\
\hline After fasting for 24 hours. . . . . . . . & .84 & 1.04 & $.8: 1$ & + \\
\hline \multicolumn{5}{|l|}{ Pernicious anemia, $\dagger$} \\
\hline Before liver therapy. .............. & 1.22 & 1.15 & $1.1: 1$ & ++ \\
\hline $8-12$ days after. . . . . . . . . . . & 1.09 & .80 & $1.4: 1$ & + \\
\hline Pernicious anemia, hyperthyroidism, & & & & \\
\hline Before liver therapy............ & 1.70 & 2.60 & $.7: 1$ & $+t+$ \\
\hline 8 days after. . . . . . . . . . . & 1.60 & 1.00 & $1.6: 1$ & ++ \\
\hline Bilirubinemia $\ddagger \ldots \ldots \ldots \ldots \ldots$ & .78 & 1.44 & $.5: 1$ & $+t$ \\
\hline Cirrhosis of liver $\S \ldots \ldots \ldots \ldots \ldots$ & 1.20 & 1.85 & $.6: 1$ & $+t+t$ \\
\hline
\end{tabular}

* Average of 3 consistent series.

† Average of 3 comparable subjects.

$\ddagger$ Average of 5 .

$\$$ Average of 2 .

with the values observed after liver therapy very much as the values for normal individuals after a twenty-four hour fast compare with the values for normal individuals after a twelve hour fast.

The catalysts of cellular metabolism may, themselves, be partially destroyed by the processes which they accelerate, much as matches are consumed by the flames they kindle. The destroyed parts of the catalysts may be excreted into the blood stream and the rate of their destruction may find reflection there in the height of the metal and bilirubin levels. 
The increased levels accompanying incipient starvation may mirror the progressive depletion, in the cell nutrient, of substances capable of protecting the iron-carrying catalysts from oxidation. Substances of the iron-sparing type may be essential constituents of liver and other extracts effective for the correction of pernicious anemia. In vitro, additions of liver extract to cultures of $\mathrm{Cl}$. welchii are as effective in stimulating the production of hemotoxin as further additions of ferrous iron (31). Pernicious anemia may be, in part, the end result of a chronic deficiency of substances capable of curbing the wasteful burning-out of the catalysts of cellular metabolism.

Brugsch and Irger (32) report an apparently quantitative relationship between the amounts of iron and bilirubin which are excreted in the bile of dogs. No parallel, inflexible relationship appears to exist in the serum of man, since we have found increased concentrations of the pigment in the serums of several persons with normal or abnormally low iron levels. Uncomplicated bilirubinemia has been accompanied by a high serum iron level without exception, as has icterus resulting from cirrhosis of the liver.

Conditions in which the iron content of the serum is decreased, the copper content remaining within the normal range

The non-hemoglobinous iron content of the serum is decreased, without significant accompanying increase or decrease in the copper level, in conditions analogous to carbon monoxide poisoning, associated with a depletion in the oxygen carrying power of the blood, and in conditions analogous to barbital poisoning, associated with a depression of the rate of intracellular oxidation.

The rabbits described in Table 3 were, for the most part, afflicted with parasitic infestations of the intestinal tract and other complications which prevented the establishment of true rabbit normals. It seemed impossible to purchase animals in perfect health. For this reason, emphasis is placed on the per cent change in the copper and iron levels, rather than on the absolute values obtained.

The test bleedings of the rabbits were followed by a fairly uniform drop of 10 to 15 per cent in the hemoglobin level, a parallel drop in the non-hemoglobinous iron level (in the absence of complications), and a 20 to 30 per cent drop in the copper level.

No further drop in the copper level was observed following the institution of bi-diurnal bleedings or of poisoning with carbon monoxide or barbital.

The decreased iron levels observed in the serums of the rabbits exposed to carbon monoxide were due, specifically, to the depleting effect of that gas upon the oxygen-carrying capacity of the blood. Control rabbits, kept in chambers ventilated in an identical manner but free of 
carbon monoxide, showed no parallel changes excepting for the initial drop of the copper and iron levels which follows the institution of weekly bleedings. Other rabbits, subjected to a depletion in blood oxygencarrying capacity comparable to that obtained with the carbon monoxide, but as the result of bi-diurnal bleedings, responded with comparable decreases in the non-hemoglobinous iron content of their serums.

The metal levels in the instances of secondary anemia, in man, which have come to our attention have been influenced principally by the complications present.

It is an interesting commentary on the faithfulness with which both the normal and the diseased organisms tend to maintain a characteristic

TABLE 3

The copper and non-hemoglobinous iron contents of the serum in conditions associated with a depression in the basal metabolic rate

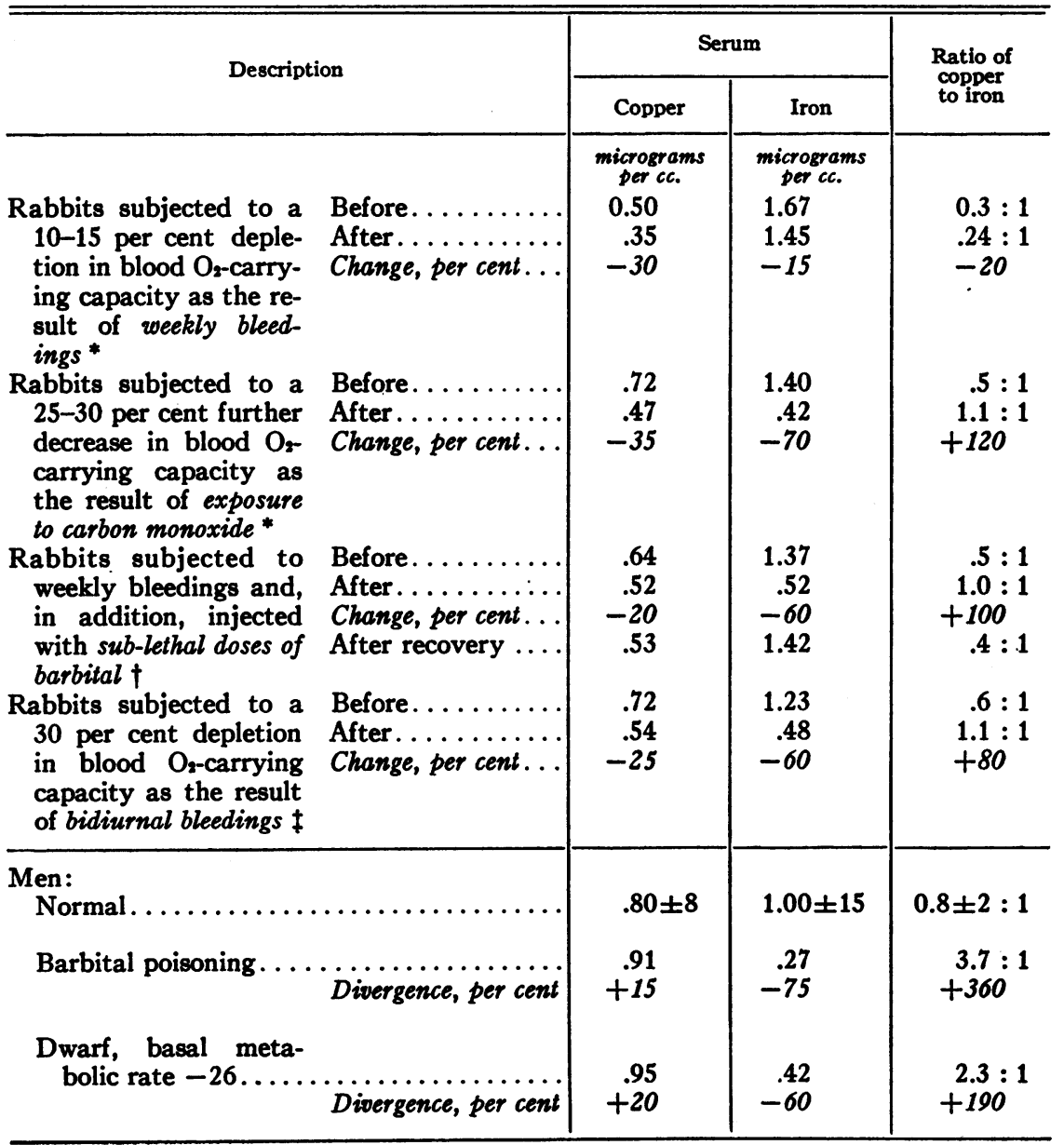


TABLE 3 (continued)

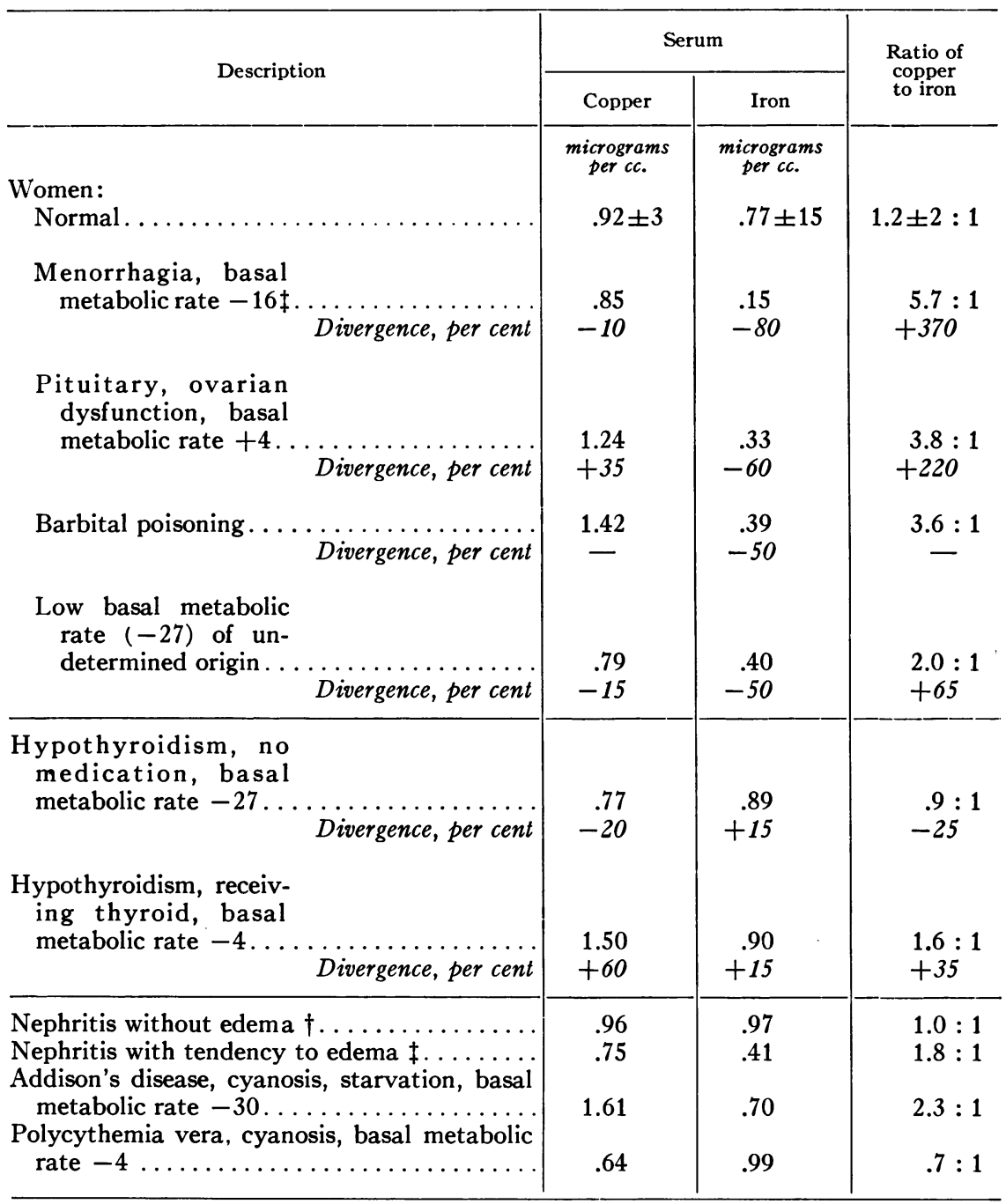

* Average of 3 consistent series.

$\dagger$ Average of 4 .

t. Average of 2.

copper-iron picture that while differences of more than 100 per cent were found in the initial copper and iron levels of the different rabbits used in the experiments reported in Table 3, those same differences were again established upon recovery from the experiences to which they were subjected. Recovery was, of course, to the status of rabbits used for weekly bleedings and not to the status of unused rabbits.

The decreased serum iron levels observed in the rabbits injected with 35 
sub-lethal doses of barbital were found also in two persons suffering with barbital poisoning. Analogous decreases were observed in two instances of menorrhagia, in one of dwarfism, and in one of combined pituitary and ovarian dysfunction.

The basal metabolic rate is reported to be lower in nephritis with edema than in nephritis without edema (33). The metal levels in the patients with Addison's disease and polycythemia vera were affected by the complications present.

The copper level in the single instance of untreated hypothyroidism available was slightly below the levels normally observed in women. The iron level was not depressed, differentiating the condition from those in which the basal metabolic rate was depressed as the result of pituitary and ovarian dysfunction.

Increases in the copper content of the serum, indicative as they are of a depletion of the copper content of the tissues and a consequent decreased extent of inhibition of cellular metabolism, tend to be accompanied by an elevation of the basal metabolic rate. This tendency may, of course, be nullified either wholly or in part as the result of complications, such as oxygen want, which tend to depress the metabolic level.

Transfer of copper from the tissues to the blood may follow the ingestion of food rich in cuprophile substances, the hypersecretion of "copperavid" hormones, or the disintegration of depots of strongly cuprophile bacteria. Or, it may follow the depletion of the cellular contents of glutathione, anionic ferrous iron, unsaturated fatty acids, and related substances with a high affinity for copper. Such depletion may follow the simple loss of these substances which occurs in starvation, the growth of neoplasms, and the development of fetuses, or it may follow the increased intensity of intracellular oxidation which accompanies an increase in body temperature. Substances of the glutathione, etc. type lose their high affinity for copper upon oxidation.

Conditions in which the copper content of the serum is increased, the iron content remaining either within or below the normal range

The copper content of the serum is increased, and the iron content decreased in conditions accompanied by a rise in body temperature. The copper content alone is changed in conditions accompanied by an elevation of the basal metabolic rate without rise in body temperature.

Sanborn (33) gives the following ranges for the basal metabolism of pregnancy, leukemia, pulmonary tuberculosis, and pernicious anemia: +33 to $+35,+21$ to $+123,+3$ to +30 , and +2 to +23 . Values of +10 to +50 are reported in carcinoma (34).

Hyperthyroidism and thyroid therapy were accompanied by an increase in the copper content of the serum, with no concomitant increase in iron content. 
The unusually high copper level reported for the instance of pregnancy accompanied by miliary tuberculosis was observed several weeks before the existence of the complication was discovered. Comparably unusual values were twice observed in rabbits with, at the time, no other conclusive evidence of abnormality. The animals later developed large cysts and had to be sacrificed.

Normal pregnancy appeared to be associated, at term, with an in-

TABLE 4

The copper and non-hemoglobinous iron contents of the serum in conditions associated with an elevation of the metabolic rate

\begin{tabular}{|c|c|c|c|}
\hline \multirow{2}{*}{ Description } & \multicolumn{2}{|c|}{ Serum } & \multirow{2}{*}{$\begin{array}{l}\text { Ratio of } \\
\text { copper } \\
\text { to iron }\end{array}$} \\
\hline & Copper & Iron & \\
\hline $\begin{array}{l}\text { Normal men.... } \\
\text { Normal women. }\end{array}$ & $\begin{array}{c}\text { micrograms } \\
\text { per cc. } \\
.80 \pm 8 \\
0.92 \pm 3\end{array}$ & $\begin{array}{c}\begin{array}{c}\text { micrograms } \\
\text { per cc. }\end{array} \\
1.00 \pm 15 \\
0.77 \pm 15\end{array}$ & $\begin{array}{l}0.8 \pm 2: 1 \\
1.2 \pm 2: 1\end{array}$ \\
\hline 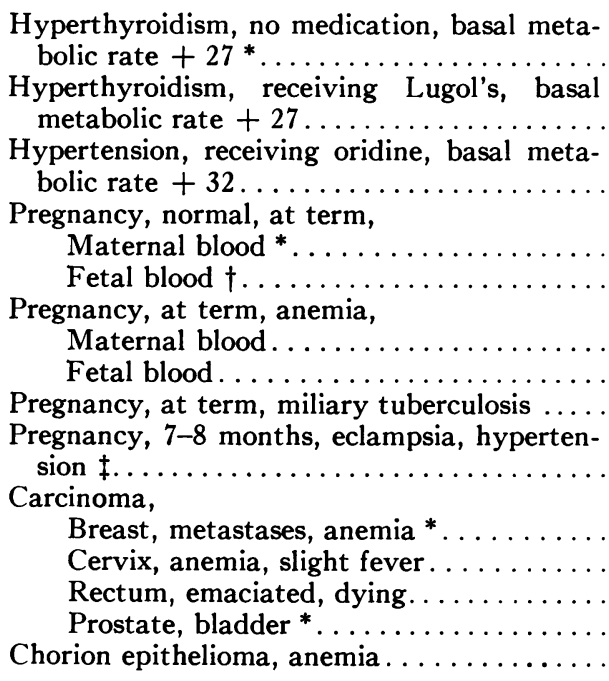 & $\begin{array}{c}1.35 \\
1.39 \\
\\
1.06 \\
2.0 \\
.53 \\
\\
1.4 \\
.50 \\
3.3 \\
\\
2.0 \\
\\
2.0 \\
1.9 \\
2.3 \\
1.4 \\
1.6\end{array}$ & $\begin{array}{c}.72 \\
.28 \\
.30 \\
\\
.8 \\
1.6 \\
\\
.4 \\
.7 \\
.8 \\
1.1 \\
\\
.9 \\
1.1 \\
1.0 \\
.48 \\
.23\end{array}$ & $\begin{array}{r}1.9: 1 \\
5.0: 1 \\
3.5: 1 \\
2.5: 1 \\
.3: 1 \\
\\
3.5: 1 \\
.7: 1 \\
4.1: 1 \\
1.8: 1 \\
\\
2.2: 1 \\
1.7: 1 \\
2.3: 1 \\
2.9: 1 \\
7.0: 1\end{array}$ \\
\hline 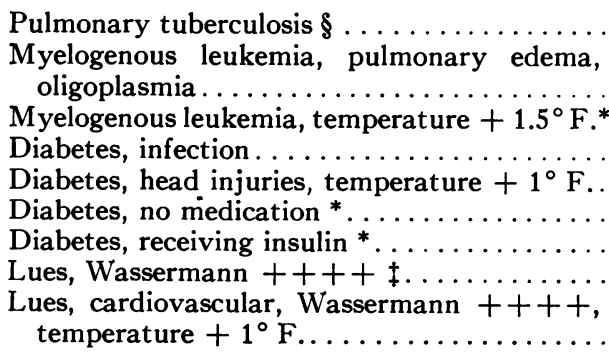 & $\begin{array}{l}1.46 \\
1.9 \\
1.36 \\
1.9 \\
1.5 \\
1.29 \\
1.06 \\
.98 \\
1.40\end{array}$ & $\begin{array}{l}.48 \\
1.2 \\
.28 \\
.46 \\
.06 \\
.40 \\
.84 \\
.89 \\
.36\end{array}$ & $\begin{aligned} 3.0 & : 1 \\
1.6 & : 1 \\
4.9 & : 1 \\
4.1 & : 1 \\
25.0 & : 1 \\
3.2 & : 1 \\
1.3 & : 1 \\
1.1 & : 1 \\
3.9 & : 1\end{aligned}$ \\
\hline
\end{tabular}


TABLE 4 (continued)

\begin{tabular}{|c|c|c|c|}
\hline \multirow{2}{*}{ Description } & \multicolumn{2}{|c|}{ Serum } & \multirow{2}{*}{$\begin{array}{l}\text { Ratio of } \\
\text { copper } \\
\text { to iron }\end{array}$} \\
\hline & Copper & Iron & \\
\hline Normal hens $\ddagger$. & $\begin{array}{l}\text { micrograms } \\
\text { per cc. } \\
.14\end{array}$ & $\begin{array}{l}\text { micrograms } \\
\text { per cc. } \\
.62\end{array}$ & $.2: 1$ \\
\hline Hens with Rous sarcoma $\ddagger$. & .19 & .36 & $.5: 1$ \\
\hline Normal horses $\ddagger \ldots \ldots \ldots \ldots \ldots$ & .90 & 1.73 & $.5: 1$ \\
\hline $\begin{array}{r}\text { Horses receiving diphtheria toxin, } \\
3-4 \text { days after last toxin injection, temper- } \\
\text { ature }+2.6^{\circ} \mathrm{F} . \| \ldots \ldots \ldots \ldots \ldots \ldots\end{array}$ & 1.59 & .96 & $1.7: 1$ \\
\hline $\begin{array}{l}\text { 5- } 6 \text { days after last toxin injection, temper- } \\
\text { ature }+0.3^{\circ} \mathrm{F} . \| \ldots \ldots \ldots \ldots \ldots \ldots \\
\text { Horses receiving tetanus toxin, }\end{array}$ & 1.29 & 1.51 & $.9: 1$ \\
\hline $\begin{array}{l}3 \text { days after last toxin injection, }+0.8^{\circ} \mathrm{F} \cdot{ }^{*} \\
5 \text { days after last toxin injection, }+0.4^{\circ} \mathrm{F}\end{array}$ & $\begin{array}{l}1.28 \\
1.01\end{array}$ & $\begin{array}{l}1.08 \\
1.66\end{array}$ & $\begin{aligned} 1.2 & : 1 \\
.6 & : 1\end{aligned}$ \\
\hline
\end{tabular}

* Average of 2 comparable subjects.

† Average of 9 .

$\ddagger$ Average of 3 .

$\S$ Average of 6 .

II Average of 4.

crease of approximately 100 per cent in the copper content of the maternal blood serum. The copper content of the serum of blood from the umbilical cord of the fetus, at delivery, was from one-third to one-fourth that of the maternal blood, while the iron content was double.

The copper contents of the brain (35) and liver (36) of the newly born child are appreciably higher than are characteristic for the normal adult. Diffusion across the placental barrier is, apparently, sufficiently slow to permit the maintenance of a different distribution between the blood and tissues of the fetus than is maintained in the maternal body.

The copper levels observed in advanced carcinoma were analogous to those observed in pregnancy. The iron levels were not consistently reduced, in either condition, excepting in the presence of complications. Changes in the serum metal levels, analogous to those found in carcinoma in man, were found also in Barred Rock hens inoculated with Rous sarcoma number 1 .

The serums of the horses were obtained through the courtesy of Eli Lilly and Co. The highest levels of serum copper, and the lowest levels of serum iron, were found in the animals reacting most severely to the toxin injections.

The highest concentrations of copper in the serums of the tuberculous subjects were present, in general, in the serums of the individuals with the 
lowest expectations of recovery. With one exception, the iron contents were below the normal level. A similar copper-iron picture was found in leukemia. No uniform changes in the copper and iron levels were observed in lues in the absence of complications.

The values for diabetes with and without insulin therapy, like those reported in Table 2 for pernicious anemia before and after liver therapy, indicate the tendency of the organism to return to a normal copper-iron balance upon the establishment of a specific therapy.

\section{SUMMARY AND CONCLUSION}

A study has been made of the copper and non-hemoglobinous iron levels in the blood serums of one hundred normal and diseased persons and of thirty-two animals used for the experimental study of the factors determining the levels observed in the human subjects. The analytical methods developed for the study are reported in detail, are accurate, rapid, and within the reach of the average clinical laboratory.

The iron content of the hemoglobin-free serum of normal persons from whom food had been withheld for 12 hours was found to vary from an average value of $1.00 \pm 15$ micrograms per cc. for young men to a value of $0.77 \pm 15$ for young women. Values of 1.4 microgram and above were observed in the serums of newly-born infants, of normal adults with mild bilirubinemia, and of persons with icterus due to cirrhosis of the liver. Intermediate values were obtained in persons subjected to 24 hour fasts, and in pernicious anemia. The increased values of the latter condition became corrected following the administration of liver extract. Normal values were found in carcinoma, pregnancy, hypo- and hyperthyroidism, and lues. Values approaching 0.4 microgram and less were observed in barbital poisoning, nephritis with edema, conditions involving pituitary and ovarian dysfunction, leukemia, pulmonary tuberculosis, and diabetes. The low values of the latter condition were corrected following insulin therapy. Experimental, recoverable depression of the iron level was obtained in rabbits subjected to hemorrhage, carbon monoxide and barbital poisoning, and in horses subjected to injections of the toxins of diphtheria and tetanus.

The copper content of the blood serum of normal persons varied from an average value of $0.80 \pm 8$ micrograms per $\mathrm{cc}$. for young men to a value of $0.92 \pm 3$ for young women. Values of 2.0 micrograms per cc. and above were found in pregnancy, at term, and in advanced carcinoma. Intermediate values were observed in toxemia, pyrogenic infection, Addison's disease, leukemia, pernicious anemia, cirrhosis of the liver, and diabetes. Approximately normal values were obtained in lues, nephritis, and conditions associated with a depressed metabolic level, excepting hypothyroidism. Slightly lowered levels were observed in hypothyroidism and polycythemia vera. Markedly lowered levels were manifest in the serum of newly born infants. 
The copper : iron ratio was below the normal averages only in conditions involving an increased serum bilirubin level. The ratio was normal in pernicious anemia, hypothyroidism, lues, and nephritis without edema. In every other condition observed, the ratio was increased, usually to a very marked degree.

An analysis of the figures reported has indicated the probable existence of four types of copper-iron picture. The first, found in incipient starvation and in pernicious anemia, may be characterized by slightly increased copper levels and markedly increased iron levels, resulting from a "burning-out" of the cell catalysts due to a depletion or deficiency in the cell nutrient of substances capable of stabilizing iron in the reduced or ferrous condition. The second, found in carbon monoxide and barbital poisoning, and in uncomplicated anemia due to hemorrhage, may be characterized by virtually unchanged copper levels and markedly decreased iron levels, as a result of the retardation in rate of "burning-out" of the cell catalysts which accompanies a depression of the basal metabolic rate. The third, found in pyrogenic infections, toxemia, leukemia, and allied conditions associated with an elevation of the body temperature, may be characterized by increases in the copper levels and decreases in the iron levels proportionate to the general severity of the conditions. The fourth, found in pregnancy, carcinoma, and hyperthyroidism, conditions associated with an elevation of the basal metabolic rate without rise in body temperature, may be characterized by markedly increased copper levels, without accompanying change in the iron levels.

A careful examination of the serum copper-iron balance before, during, and after provisional therapy may eventually prove of definite aid in the diagnosis and treatment of disease.

The writers wish to emphasize the purely exploratory character of the work which has been presented, and the provisional nature of the classifications and hypotheses suggested. Grateful acknowledgment is made of the cooperation of Dr. Edwin F. Hirsch and others of the laboratory and staffs of St. Luke's Hospital, Eli Lilly and Co., and the Municipal Tuberculosis Sanitarium, who provided essential material and assistance.

\section{BIBLIOGRAPHY}

1. Glaser, O., Biol. Bull., 1923, xliv, 79. Copper, Enzymes and Fertilization.

2. Cook, S. F., U. of Calif. Pub. in Physiol., 1930, vii, 223. The Effect of Iron, Copper, and Manganese on the Respiration of Yeast.

3. Krebs, H. A., Biochem. Z schr., 1930, ccxx, 289. Versuche über die proteolytische Wirkung des Papains.

4. Stern, K. G., Biochem. Ztschr., 1931, ccxxxiv, 116 . Über die autolytische Wirksamkeit der tierischen Gewebsproteinasen und ihre Beeinflussung durch Schwermetalle.

5. Corran, R. F., Biochem. J., 1929, xxiii, 188. The Influence of Various Substances on Lipase Action. 
6. Parfentjev, I. A., Devrient, W. C., and Sokoloff, B. F., J. Biol. Chem., 1931, xcii, 33. The Influence of Sodium Taurocholate and Copper Sulphate on Lipase.

7. Locke, A., and Main, E. R., J. Infect. Dis., 1930, xlvi, 393. The Respiratory Catalysts of the Disease-Producing Bacteria.

8. Loevenhart, A. S., Arch. Int. Med., 1915, xv, 1059. Certain Aspects of Biological Oxidation.

9. Warburg, O., Biochem. Ztschr., 1929, cciv, 482. Ist die aerobe Glykolyse spezifisch für die Tumoren?

10. Warburg, O., and Krebs, H. A., Biochem. Ztschr., 1927, cxc, 143. Über locker gebundenes Kupfer und Eisen im Blutserum.

11. Warburg, O., Klin. Wchnschr., 1927, vi, 1094. Über Kupfer im Blutserum des Menschen.

12. Krebs, H. A., Klin. Wchnschr., 1928, vii, 584. Über das Kupfer in menschlichen Blutserum.

13. Schindel, L., Klin. Wchnschr., 1931, x, 743. Über den Kupfergehalt des Blutes.

14. Schönheimer, R., and Oshima, F., Ztschr. f. physiol. Chem., 1929, clxxx, 249. Der Kupfergehalt normaler und pathologischer Organe. I. Methodik.

15. Biazzo, R., Ann. chim. applicata, 1926, xvi, 96. Rapid Method for the Determination of Copper in Preserved Vegetable Products Which Have Been Colored Green Artificially.

16. Flinn, F. B., and Inouye, J. M., J. Biol. Chem., 1929, lxxxiv, 101. Some Physiological Aspects of Copper in the Organism.

17. Kleinmann, H., and Klinke, J., Virchows Archiv f. path. Anat. u. Physiol., 1930, cclxxv, 422. Über den Kupfergehalt menschlicher Organe.

18. Herkel, W., Beitr. z. path. Anat. u. z. allg. Path., 1930, lxxxv, 513. Über die Bedeutung des Kupfers in der Biologie und Pathologie.

19. Grendel, F., Pharm. Weekblad, 1930, lxvii, 1345. A Micro Determination of Copper in Blood.

20. McHargue, J. S., Am. J. Physiol., 1925, lxxii, 583. The Association of Copper with Substances Containing the Fat-Soluble A Vitamin.

21. Abderhalden, E., and Möller, P., Ztschr. f. physiol. Chem., 1928, clxxvi, 95. Untersuchungen über den Gehalt des Blutserums an Eisen, Kupfer und Mangan.

22. Elvehjem, C. A., Steenbock, H., and Hart, E. B., J. Biol. Chem., 1929, lxxxiii, 21. Is Copper a Constituent of the Hemoglobin Molecule? The Distribution of Copper in Blood.

23. Riecker, H. H., Arch. Int. Med., 1930, xlvi, 458. Iron Metabolism in Pernicious and in Secondary Anemia.

24. Riecker, H. H., and Winters, M. E., Am. J. Physiol., 1930, xcii, 196. Serum Iron Determinations Applied to the Study of Experimental Anemia.

25. Fontès, G., and Thivolle, L., Compt. rend. Soc. de biol., 1925, xciii, 687. Sur la Teneur du Sérum en Fer non Hémoglobinique et sur sa Diminution au Cours de l'Anémie Expérimentale.

26. Barkan, G., Klin. Wchnschr., 1927, vi, 1615. Über Säurelösliches Eisen im Blutserum.

27. Starkenstein, E., and Weden, H., Arch. f. exper. Path. u. Pharm., 1928, cxxxiv, 274, 288. Über das anorganische Eisen des Organismus.

28. Henriques, V., and Roche, A., Bull. Soc. chim. biol., 1927, ix, 501. Sur le Fer du Sérum Sangúin de Diverses Espèces Animales. 
29. Callan, T., and Henderson, J. A. R., Analyst, 1929, liv, 650. New Reagent for the Colorimetric Determination of Minute Amounts of Copper.

30. Kennedy, R. P., J. Biol. Chem., 1927, lxxiv, 385. The Quantitative Determination of Iron in Tissues.

31. Locke, A., and Main, E. R., J. Infect. Dis., 1931, xlviii, 419. The Relation of Copper and Iron to Production of Toxin and Enzyme Action.

32. Brugsch, T., and Irger, J., Ztschr. f. d. ges. exper. Med., 1926, 1, 625. Über die Ausscheidung des Eisens durch die Galle nach intravenöser und nach oraler Einverleibung von Eisenpräparaten bei ungeschädigter und durch Toluylendiamin geschädigter Leber.

33. Sanborn, F. B., Basal Metabolism, Its Determination and Application. Boston, Sanborn Co., 1922.

34. Strieck, F., and Mulholland, H. B., Deutsches Archiv f. klin. Med., 1928, clxii, 51. Untersuchungen über den Gaswechsel bei Kranken mit malignen Tumoren.

35. Bodansky, M., J. Biol. Chem., 1921, xlviii, 361. The Zinc and Copper Content of the Human Brain.

36. Morrison, D. B., and Nash, T. P., Jr., J. Biol. Chem., 1930, 1xxxviii, 479. The Copper Content of Infant Livers. 